\title{
Mild encephalitis/encephalopathy with a reversible splenial lesion (MERS) following influenza virus infection
}

\author{
Issei Takahashi, Hiroyuki Yano, Mitsuyo Kinjo
}

Department of Medicine, Okinawa Chubu Hospital, Uruma, Japan

Correspondence to Dr Mitsuyo Kinjo; kinjomitsuyo@gmail.com

Accepted 23 April 2020
Check for updates

(C) BMJ Publishing Group Limited 2020. No commercial re-use. See rights and permissions. Published by BMJ.

To cite: Takahashi I, Yano H, Kinjo M. BMJ Case Rep 2020;13:e235461. doi:10.1136/bcr-2020235461

\section{DESCRIPTION}

A 50-year-old man presented to the emergency department with fever, altered mental status, incoherent speech and involuntary movements. He had a high-grade fever with upper respiratory symptoms 9 days prior, and was diagnosed with influenza B infection by rapid antigen test, for which he was prescribed antipyretics without antiviral medication. Over the 4 days prior to admission, he became gradually unarousable, with random incoherent speech and unintentional muscle twitching, prompting his family to bring him for evaluation. The patient had untreated hypertension and his family history was unremarkable.

On presentation, his body temperature was $38.3^{\circ} \mathrm{C}$ and other vitals were unremarkable. He was disoriented to time and place. General examination was unremarkable, but neurological examination revealed myoclonus in both arms, an inability to stand on his feet and neck stiffness with a positive Kernig's sign. Laboratory data showed mild hyponatremia $(132 \mathrm{mEq} / \mathrm{L})$. CT of the brain was unremarkable. Cerebrospinal fluid obtained from a lumbar puncture showed elevated white cells of $0.14 \times 10^{9} / \mathrm{L}$ with predominance of lymphocytes (98\%) and a protein level of $257 \mathrm{mg} / \mathrm{dL}$. An MRI scan of the brain revealed high intensity in the centre of the splenium of corpus callosum (SCC) on diffusion-weighted imaging (DWI) (figure 1A). Hypointensity in the same region was noted on an apparent diffusion coefficient (ADC) map (figure 1B) indicating mild encephalitis/encephalopathy with a reversible splenial lesion (MERS) after influenza infection. The differential diagnosis of these MRI findings included splenial ischaemia, acute disseminated encephalomyelitis, multiple sclerosis and lymphoma. ${ }^{1}$

The patient was treated with intravenous acyclovir and cefotaxime until microbiology testing ruled

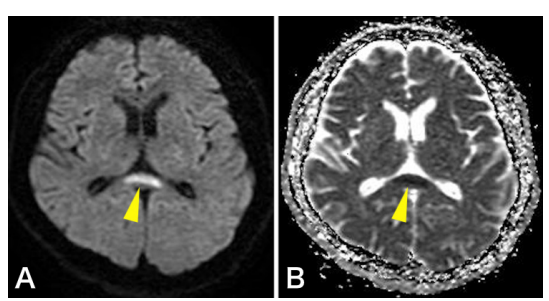

Figure $1 \mathrm{MRI}$ of the brain revealed high intensity in the centre of the splenium of corpus callosum on diffusionweighted imaging $(A)$ and hypointensity on apparent diffusion coefficient map (B) (yellow arrowheads).

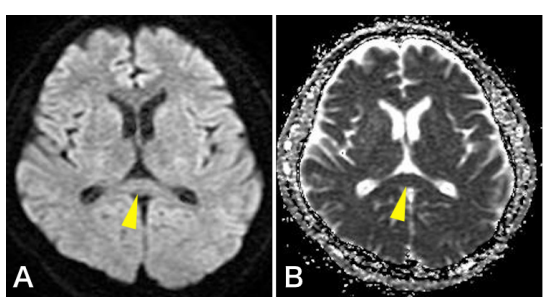

Figure 2 Follow-up MRI of the brain showed complete resolution of the lesion on diffusion-weighted imaging (A) and apparent diffusion coefficient map (B) (yellow arrowheads).

out herpes simplex virus and bacterial meningitis. After 10 days of supportive care, there was nearly complete resolution of neurological symptoms. A follow-up MRI showed complete resolution of the high-intensity signal from the SCC (figure 2), establishing the diagnosis of MERS following influenza infection. The patient was discharged ambulatory on day 12 .

MERS, not to be confused with Middle East respiratory syndrome due to coronavirus, was first described in 15 patients with acute but transient encephalitis/encephalopathy with characteristic splenial lesions. ${ }^{2}$ MERS is a clinico-radiological syndrome with a good prognosis characterised by transient MRI findings; high-intensity signals in the SCC were observed on DWI, $\mathrm{T}_{2}$-weighted images and fluid-attenuated inversion recovery images, along with low-intensity lesions on ADC maps. ${ }^{3}$ MERS is a well-known condition in children, but rarely occurs in adults. Clinical appearance includes central nervous system symptoms such as altered sensorium, seizures, delirium and headache.

\section{Learning points}

- Mild encephalitis/encephalopathy with a reversible splenial lesion (MERS) is a clinicoradiological syndrome with a good prognosis characterised by transient MRI findings.

- Clinical appearance includes central nervous system symptoms such as altered sensorium, seizures, delirium and headache.

- MERS may follow viral infections such as influenza, mumps or rotavirus, and also bacterial infections such as Legionella pneumonia, Mycoplasma pneumonia or Salmonella enteritidis. 
Complete recovery typically occurs within 1 month. ${ }^{2}$ MERS may follow viral infections such as influenza, mumps or rotavirus, and also bacterial infections such as Legionella pneumonia, Mycoplasma pneumonia or Salmonella enteritidis. ${ }^{3}$ The predilection of MERS for the SCC is unexplained, although hypotheses to explain the mechanism of MERS include intramyelinic axonal oedema, inflammatory infiltrates, oxidative stress and fluid imbalance. ${ }^{4}$

Early imaging, along with comprehensive evaluation for meningitis, viral encephalitis or other neurological diseases, is necessary for the diagnosis of MERS.

\section{Acknowledgements Dr Rita McGill edited language.}

Contributors IT wrote the manuscript, collected data and contributed to overall writing. HY wrote the manuscript, collected and edited data and contributed to the entire manuscript. MK contributed to writing the manuscript.
Funding The authors have not declared a specific grant for this research from any funding agency in the public, commercial or not-for-profit sectors.

Competing interests None declared.

Patient consent for publication Obtained.

Provenance and peer review Not commissioned; externally peer reviewed.

\section{ORCID iD}

Mitsuyo Kinjo http://orcid.org/0000-0002-8342-230X

\section{REFERENCES}

1 Friese SA, Bitzer M, Freudenstein D, et al. Classification of acquired lesions of the corpus callosum with MRI. Neuroradiology 2000;42:795-802.

2 Tada H, Takanashi J, Barkovich AJ, et al. Clinically mild encephalitis/encephalopathy with a reversible splenial lesion. Neurology 2004;63:1854-8.

3 Yuan J, Yang S, Wang S, et al. Mild encephalitis/encephalopathy with reversible splenial lesion (MERS) in adults-a case report and literature review. BMC Neurol 2017:17:103.

4 Shi B-C, Li J, Jiang J-W, et al. Mild encephalitis/encephalopathy with a reversible splenial lesion secondary to encephalitis complicated by hyponatremia: a case report and literature review. Medicine 2019;98:e17982.

Copyright 2020 BMJ Publishing Group. All rights reserved. For permission to reuse any of this content visit

https://www.bmj.com/company/products-services/rights-and-licensing/permissions/

BMJ Case Report Fellows may re-use this article for personal use and teaching without any further permission.

Become a Fellow of BMJ Case Reports today and you can:

- Submit as many cases as you like

Enjoy fast sympathetic peer review and rapid publication of accepted articles

Access all the published articles

Re-use any of the published material for personal use and teaching without further permission

\section{Customer Service}

If you have any further queries about your subscription, please contact our customer services team on +44 (0) 2071111105 or via email at support@bmj.com.

Visit casereports.bmj.com for more articles like this and to become a Fellow 